\title{
ANALISIS BAKTERI Escherichia coli PADA MAKANAN SIAP SAJI DI KANTIN RUMAH SAKIT X DAN KANTIN RUMAH SAKIT Y
}

\author{
Inggit Saridewi ${ }^{1}$, Arief Pambudi ${ }^{1}$, dan Yulia Fitria Ningrum ${ }^{2 *}$ \\ ${ }^{1}$ Program studi Biologi, Fakultas Sains dan Teknologi Universitas Al Azhar Indonesia, ${ }^{2}$ Balai Besar Teknik \\ Kesehatan Lingkungan Dan Pengendalian Penyakit Jakarta \\ *Email: tsuki_fitri@yahoo.com
}

\begin{abstract}
The increasing human activity makes the preference for fast food increases. However, some people do not pay attention to the hygiene conditions of food processed from food stalls. Food handlers, equipment utilization, food processing, clean water, and the packaging are the critical points of bacterial contamination. Escherichia coli is a bacterium that usually used as the indicator of food hygiene. The objective of this study is to examine the contamination of coliform bacteria, especially E. coli at two hospital cafeteria by using MPN method and questionnaire regarding the implementation of the basic principles of hygiene. Stages of tests performed that are the presumption test, confirmation test, complementary test, gram stain test, biochemical test IMViC and supported by a questionnaire. From the two locations tested, some samples showed positive result in a presumption test and confirmation test but negatively complementary to biochemical test. This indicates that the sample does not contain E. coli bacteria in food, but there is the possibility of Citrobacter. The negative results of the IMVIC test showed that it is possible bacteria found in the presumption test and confirmation test not E. coli and non-pathogenic bacteria. Based on the results of the questionnaire, most of restaurant owner has understood to served food. Food at the hospital $X$ and $Y$ cafetaria are safe to consume because it has a negative E.coli.
\end{abstract}

Keywords: biochemistry IMViC, Escherichia coli, fast food, hygiene and sanitation.

\section{PENDAHULUAN}

Salah satu kebutuhan pokok bagi manusia atau hewan adalah makanan yang berfungsi untuk pertumbuhan dan perkembangan, memperoleh energi, mengatur metabolisme serta berperan di dalam mekanisme pertahanan tubuh terhadap berbagai penyakit (Notoatmodjo 2003). Perkembangan teknologi dapat mengubah gaya hidup masyarakat seperti berubahnya pola hidup seseorang dengan lebih banyak mengkonsumsi makanan siap saji daripada makanan yang bergizi dan alami (Ngafifi 2014).

Kehadiran makanan siap saji di kalangan masyarakat menjadikan makanan tersebut lebih dipilih karena dianggap lebih efisien. Makanan siap saji memiliki keunggulan namun memiliki resiko bagi kesehatan karena pengolahan makanan yang tidak higienis sehingga memungkinkan makanan terkontaminasi bakteri berbahaya, selain itu lokasi dari makanan siap saji berada sangat berpengaruh seperti rumah sakit yang memungkinkan terjadinya penyebaran penyakit atau kontaminasi bakteri (Depkes RI 2004), sehingga pengunjung kantin dan penjaga kantin cenderung memiliki imunitas rendah, selain itu rumah sakit memiliki sumber pencemar seperti limbah infeksius dan limbah patologi, limbah farmasi (obat kadaluarsa), limbah sitotoksis, limbah medis padat tajam, serta limbah 
radioaktif (Depkes RI 2004).

Kontaminasi sering berada pada makanan adalah Escherichia coli yang menyebabkan diare. Diare merupakan penyakit yang menjadikan seseorang buang air besar dengan tekstur lunak bahkan berupa air saja dalam jangka waktu sedikit namun terjadi lebih dari 3 kali (Depkes RI 2011). Menurut Surveilan Terpadu Penyakit (STP) puskesmas dan rumah sakit (RS) angka insiden diare selama lima tahun dari tahun 2002 sampai tahun 2006 cenderung berfluktuasi dari 6,7 per 1000 pada tahun 2002 menjadi 9,6 per 1000 pada tahun 2006 (angka insiden bervariasi antara 4,5-25,7 per 1000), sedangkan dari Survei Kesehatan Rumah Tangga (SKRT) tahun 2001 penyakit diare menduduki urutan ke dua dari penyakit infeksi dengan angka morbiditas sebesar 4,0\% dan mortalitas 3,8\%.

Syarat utama dalam menentukan kualitas makanan yang baik adalah dengan meninjau ilmu sanitasi karena secara langsung maupun tidak langsung lingkungan kita berhubungan dengan mengolah atau menyediakan makanan (Marwanti 2010). Banyaknya makanan yang kurang diperhatikan oleh pengelola sehingga dapat mengakibatkan penyakit, maka perlu dilakukan penelitian terhadap makanan siap saji di kantin rumah sakit karena memiliki populasi rentan bakteri serta sumber kontaminasi sehingga dilakukan identifikasi bakteri E. coli yang paling banyak pada makanan dan minuman.

\section{METODOLOGI}

\section{WAKTU DAN TEMPAT PENELITIAN}

Penelitian dilakukan pada bulan Agustus 2016 - Oktober 2016. Lokasi penelitian di Balai Besar Teknik Kesehatan Lingkungan dan Pengendalian Penyakit JakartA. Pengambilan sampel makanan dilakukan di kantin Rumah sakit X dan kantin Rumah Sakit Y. Penelitian ini dilakukan dengan menggunakan metode Most Probable Number (MPN) kemudian dilakukan uji biokimia.

\section{ALAT DAN BAHAN}

Alat yang digunakan adalah tabung reaksi, tabung durham, cawan petri, pipet mikro $1000 \mu \mathrm{l}$ dan $10 \mu \mathrm{l}$, jarum ose, bunsen, blender steril, autoklaf, laminar air flow, dan inkubator. Bahan yang digunakan adalah sampel makanan, biakan E. coli, Lauryl trypstose Broth (LB), Eschericia coli Broth (ECB), Eosin Metylen Blue Agar (EMBA), Tryptone Broth, media Metyl Red-Voges Proskauer (MR-VP), Reagen kovac, $\alpha$ - Napthol, KOH 40\%, dan koser citrate broth.

\section{LANGKAH KERJA}

Pengambilan sampel

Sampel makanan diambil dari kantin di seluruh Rumah sakit X dan Rumah Sakit Y yang berjumlah 34 sampel. Pengambilan sampel menggunakan plastik steril dan bunsen.

\section{Persiapan sampel}

Sampel makanan di ambil dari plastik sampel kemudian ditimbang sebanyak 50gr. Sampel kemudian dihancurkan bersama Buffer field phosphate (BPS) sebanyak 450ml dengan blender hingga homogen. Sampel yang telah hancur, siap untuk digunakan.

Prosedur Pemeriksaan Pada Sampel

Sampel dilakukan dengan menggunakan uji Most Probable Number (MPN). 


\section{Pengenceran}

Sampel makanan yang telah dihomogenkan dengan Buffer field phosphate (BPS) sebanyak $450 \mathrm{ml}$, kemudian dilakukan pengenceran dengan memasukkan sampel pada botol pertama (10-1) sebanyak $10 \mathrm{ml}$. Pada botol pertama (10-1) diambil $10 \mathrm{ml}$ lalu memasukkan ke dalam botol kedua(10-2) yang telah diberi larutan Buffer field phosphate (BPS) sebanyak $450 \mathrm{ml}$. Pada botol kedua diambil $10 \mathrm{ml}$ lalu memasukkan ke botol ketiga (10-3) yang telah diberi larutan Buffer field phosphate (BPS) sebanyak $450 \mathrm{ml}$ (Gambar 2).

\section{Tes Perkiraan (Presumtive Test)}

Pada tes perkiraan disiapkan 9 tabung (seri 3-3-3) untuk pengenceran bertingkat. Disiapkan 9 tabung, masing masing berisi $9 \mathrm{ml}$ Lauryl Tryptose Broth (LB) untuk tabung seri pertama (10-1) dan $9 \mathrm{ml}$ untuk seri kedua (10-2) dan $9 \mathrm{ml}$ untuk seri ketiga(10-3). Pada 3 tabung seri pertama (10-1) dimasukkan $1 \mathrm{ml}$ sampel makanan yang telah dilarutkan dengan menggunakan pelarut BPS pada botol pertama (10-1). Pada 3 tabung seri kedua(10-2) dimasukkan $1 \mathrm{ml}$ sampel makanan yang telah dilarutkan dengan pelarut BPS pada botol kedua (10-2). Pada 3 tabung seri ketiga(10-3) dimasukkan $1 \mathrm{ml}$ sampel makanan yang telah dilarutkan dengan BPS pada botol ketiga (10-3) (Gambar 3). 15 tabung yang telah terisi sampel diinkubasi selama 24 jam pada suhu 37oC dan diamati apakah terbentuk gas pada tiap-tiap tabung. Terbentuknya gas menandakan tes perkiraan positif dan dilanjutkan ke tes penegasan. Media LTB digunakan sebagai medium untuk mendeteksi kehadiran koliform dalam air dan makanan.

\section{Tes Penegasan (Confirmed Test)}

Hasil sampel yang positif pada tes perkiraan dapat dilanjutkan dengan memasukkan sampel positif ke dalam media EC broth untuk uji bakteri E. coli. Untuk uji E. coli, ditanam 1-3 ose biakan positif gas ke dalam tabung yang berisi $10 \mathrm{ml} \mathrm{ECB} \mathrm{yang} \mathrm{didalamnya} \mathrm{terdapat} \mathrm{tabung} \mathrm{durham} \mathrm{terbalik.} \mathrm{Sampel} \mathrm{diinkubasi} \mathrm{selama} \mathrm{24-48} \mathrm{jam} \mathrm{pada}$ suhu 44oC. Diamati tabung yang didalamnya terdapat gas. Banyaknya perkiraan kandungan E. coli dapat dilihat dan dibandingkan dengan tabel MPN.

\section{Tes Pelengkap (Completed Test)}

Hasil positif pada media EC Broth kemudian ditumbuhkan pada media Eosin Metilen Blue Agar (EMBA) dan hasil yang positif dilanjutkan dengan pemeriksaan uji biokimia. Media EMBA adalah media selektif dan diferensial yang digunakan untuk isolasi bakteri gram negatif dari spesimen klinis dan non-klinis. Tes pelengkap dilakukan dengan menanam hasil positif EC Broth sebanyak 1-3 ose ke media EMBA. Sampel diinkubasi selama 18-24 jam pada suhu 37oC. Hasil positif pada media EMBA (ditandai dengan penampakan fisik warna hijau metalik).

\section{Pewarnaan gram}

Hasil positif yang ditunjukan pada media EMBA dapat dilanjutkan dengan pewarnaan gram untuk membedakan jenis gram bakteri gram positif dan gram negatif. Pewarnaan gram diawali dengan pembuatan preparat terlebih dahulu dari bakteri yang digunakan. Preparat diperoleh dari 1-3 ose biakan positif media EMB lalu diletakan di preparat dan diberikan 1-2 tetes larutan BPS kemudian dikeringkan. Preparat yang telah kering diberi 1 tetes larutan kristal violet yang didiamkan selama 1 menit serta dibilas dengan air yang mengalir. Kemudian, diberi larutan lugol yang didiamkan selama 1 menit dan dibilas dengan air yang mengalir. Setelah itu, di tambahkan aseton hingga warna pada preparat menghilang, sehingga dapat dilakukan penambahan safranin selama 15 detik dan dibilas dengan air yang mengalir. Proses selanjutnya adalah pengeringan yang dilanjutkan dengan pengamatan dengan mikroskop dengan perbesaran 100 kali.

Pengujian Biokimia (IMVIC)

Uji Indol. Biakan EMBA ditaman 1 ose ke dalam tryptone broth. Diinkubasi selama 24 jam pada suhu 37 oC. 
Setelah itu, ditambahkan 3-5 tetes pereaksi indol. Di homogenkan lalu didiamkan selama beberapa menit. Uji indol akan menunjukkan hasil positif bila larutan terdapat cincin merah.

Uji Merah Metil. Biakan EMBA ditanam 1 ose ke dalam MR-VP. Diinkubasi selama 24 jam pada suhu 37oC. Kemudian ditambahkan 3-5 tetes merah metil. Di homogenkan lalu didiamkan selama beberapa menit. Uji merah metil (Methyl Red) akan menunjukkan hasil positif bila larutan berwarna merah.

Uji VP (Voges Proskauer). Biakan EMBA ditanam 1 ose ke dalam MR-VP. Diinkubasi selama 24 jam pada suhu 37oC. Setelah itu, ditambahkan 0,6 ml larutan alfa naftol dan 0,2 ml larutan $\mathrm{KOH} \mathrm{40 \% .} \mathrm{Di} \mathrm{homogenkan}$ lalu didiamkan selama beberapa menit. Uji VP (Voges Proskauer) akan menunjukkan hasil positif bila larutan menunjukkan warna merah.

Uji Sitrat. Biakan EMBA ditanam 1 ose ke dalam simmons sitrat. Diinkubasi selama 24 jam pada suhu 37oC. Uji sitrat akan menunjukkan hasil positif bila tidak terjadi pertumbuhan dan tidak mengeluarkan warna keruh.

\section{Pembuatan Kontrol}

Kontrol pada penelitian ini menggunakan biakan E. coli untuk control positif dan E. aerogenes untuk control negatif. Biakan E. coli dan E. aerogenes diberi perlakuan sama dengan prosedur pemeriksaan pada sampel makanan.

\section{Kuisioner}

Kuisioner diperoleh berdasarkan peraturan MENKES 1096 Tahun 2011 dan KEPMENKES No. 942/ Menkes/SK/VII/2003

\section{HASIL DAN PEMBAHASAN}

\section{METODE MOST PROBABLE NUMBER (MPN)}

Penelitian yang diperoleh dari kantin rumah sakit $\mathrm{X}$ dan kantin rumah sakit $\mathrm{Y}$ menghasilkan nilai most probable number (MPN) seperti pada Tabel 1 dan Tabel 2.

Dari hasil penelitian yang telah diperoleh dari kantin rumah sakit $\mathrm{X}$ adalah terbentuknya gas pada uji perkiraan dengan media LTB yang menunjukkan adanya kehadiran bakteri koliform (Bridson 2006), serta terbentuknya gas pada uji penegasan dengan media EC Broth untuk diferensiasi koliform dan uji konfirmasi E.coli dari makanan (Lal \& Cheepthman 2007), namun pada uji pelengkap tidak terbentuknya perubahan warna yang menunjukkan negatif bakteri E.coli sehingga tidak dilakukan uji biokimia IMVIC lebih lanjut.

Dari hasil penelitian yang telah diperoleh dari kantin rumah sakit $\mathrm{Y}$ adalah terbentuknya gas pada uji perkiraan dengan media LTB dan uji penegasan dengan media EC Broth. Pada uji pelengkap hanya satu sampel yang mengalami perubahan warna menjadi hijau metalik sehingga diduga positif bakteri E.coli, kemudian dilakukan uji biokimia IMVIC lebih lanjut untuk mengkofirmasi hasil pada uji pelengkap. Hasil dari uji biokimia IMVIC adalah indol negatif, metil red positif, Voges Proskauer negatif dan sitrat positif.

Metode yang dilakukan dengan metode MPN untuk menghitung jumlah bakteri dalam mendeteksi adanya kontaminasi bakteri dengan media cair yang merupakan kontaminan. Metode MPN juga dapat digunakan untuk pemeriksaan air yang dilakukan untuk mengetahui kontaminasi akibat bakteri koliform dan koli tinja (Sunardi 2014), sehingga penelitian ini melakukan pemeriksaan pada air. Penelitian yang diperoleh dari kantin rumah sakit $X$ dan kantin rumah sakit Y menghasilkan nilai most probable number (MPN) seperti pada Tabel 3 dan Tabel 4. 
Dari hasil penelitian tes perkiraan MPN koliform pada air menunjukkan bahwa 7 dari 8 sampel mengandung bakteri golongan koliform. Tabung yang dinyatakan positif akan menunjukkan terbentuknya gas di dalam tabung durham dan terjadi kekeruhan pada media LTB double. Hasil positif pada tes ini harus dilanjutkan pada tes selanjutnya dengan menanam sampel yang positif pada media Briliant Green Lactosa Broth (BGLB) untuk melihat nilai MPN koliformnya (Tristyanto 2016).

Tabel 1. Hasil uji MPN pada makanan yang dilakukan pada kantin rumah sakit X

\begin{tabular}{|c|c|c|c|c|c|c|c|}
\hline & Perkiraan & Penegasan & Pelengkap & Uji Bic & imia & & \\
\hline Nomor Sampel & $\begin{array}{l}\text { LTB Single } \\
(\mathrm{MPN} / \mathrm{g})\end{array}$ & E.C Broth & & Indol & MR & $\mathrm{VP}$ & Citrat \\
\hline$(\mathrm{MPN} / \mathrm{g})$ & EMBA & & & & & & \\
\hline$(\mathrm{MPN} / \mathrm{g})$ & Indol & MR & VP & Citrat & & & \\
\hline 4893 & 36 & 16 & $<3.0$ & - & - & - & - \\
\hline 4892 & $>1100$ & 36 & $<3.0$ & - & - & - & - \\
\hline 4891 & 3.6 & $<3.0$ & $<3.0$ & - & - & - & - \\
\hline 4890 & $<3.0$ & $<3.0$ & $<3.0$ & - & - & - & - \\
\hline 4889 & 7.4 & 3.6 & $<3.0$ & - & - & - & - \\
\hline 4888 & 460 & 150 & $<3.0$ & - & - & - & - \\
\hline 4887 & $>1100$ & $>1100$ & $<3.0$ & - & - & - & - \\
\hline 4886 & $>1100$ & 36 & $<3.0$ & - & - & - & - \\
\hline 4885 & $<3.0$ & $<3.0$ & $<3.0$ & - & - & - & - \\
\hline 4884 & $>1100$ & $>1100$ & $<3.0$ & - & - & - & - \\
\hline 4883 & $>1100$ & $>1100$ & $<3.0$ & - & - & - & - \\
\hline 4882 & $>1100$ & 16 & $<3.0$ & - & - & - & - \\
\hline 4881 & 460 & 460 & $<3.0$ & - & - & - & - \\
\hline 4880 & $<3.0$ & $<3.0$ & $<3.0$ & - & - & - & - \\
\hline 4879 & 3.6 & $<3.0$ & $<3.0$ & - & - & - & - \\
\hline 4878 & 3.6 & $<3.0$ & $<3.0$ & - & - & - & - \\
\hline 4877 & 75 & 75 & $<3.0$ & - & - & - & - \\
\hline 4876 & $<3.0$ & $<3.0$ & $<3.0$ & - & - & - & - \\
\hline Kontrol positif & & & & + & + & - & - \\
\hline Kontrol negatif & & & & - & - & - & + \\
\hline
\end{tabular}

Tabung yang menunjukkan hasil positif pada media LTB double akan menunjukkan terbentuknya gas dan terjadi kekeruhan. Hasil positif yang ditunjukkan pada uji ini harus dilanjutkan pada uji selanjutnya dengan menanam sampel positif pada media Briliant Green Lactosa Broth (BGLB) untuk melihat nilai MPN koliformnya (Tristyanto 2016). Dari hasil penelitian ini menunjukkan bahwa 3 dari 4 sampel mengandung bakteri golongan koliform.

Menurut permenkes nomor 492 tahun 2010, kualitas air yang memenuhi syarat untuk total koliform dan E.coli adalah $0 \mathrm{koloni} / \mathrm{ml}$ sampel. Pengendalian pencemaran air adalah upaya pencegahan dan penanggulangan pencemaran air serta pemulihan kualitas air untuk menjamin kualitas air agar sesuai dengan baku mutu air (PP RI 2001).

\section{PERKIRAAN (PRESUMTIVE TEST)}

Penelitian yang dilakukan pada uji perkiraan mendapatkan hasil yang di peroleh dari kantin rumah sakit X adalah 14 sampel positif dan 4 sampel negatif sedangkan kantin rumah sakit $Y$ adalah 8 sampel positif dan 8 sampel negatif. Uji perkiraan ini dinyatakan positif apabila terbentuknya gas dalam tabung durham (Gambar 1). 
Tabel 2. Hasil uji MPN pada makananyang dilakukan pada kantin rumah sakit $Y$

\begin{tabular}{|c|c|c|c|c|c|c|c|}
\hline \multirow[b]{2}{*}{ Nomor Sampel } & \multirow{2}{*}{$\begin{array}{c}\text { Perkiraan } \\
\text { LTB Single } \\
(\mathrm{MPN} / \mathrm{g})\end{array}$} & \multirow{2}{*}{$\begin{array}{l}\text { Penegasan } \\
\text { E.C Broth } \\
(\mathrm{MPN} / \mathrm{g}) \\
\end{array}$} & \multirow{2}{*}{$\begin{array}{c}\text { Pelengkap } \\
\text { EMBA } \\
(\mathrm{MPN} / \mathrm{g})\end{array}$} & \multicolumn{4}{|c|}{ Uji Biokimia } \\
\hline & & & & Indol & MR & VP & Citrat \\
\hline 4917 & $>1100$ & 36 & $<3.0$ & - & - & - & - \\
\hline 4916 & 3.6 & 3.6 & $<3.0$ & - & - & - & - \\
\hline 4915 & $>1100$ & 36 & $<3.0$ & - & - & - & - \\
\hline 4914 & $>1100$ & 35 & 7.4 & - & + & - & + \\
\hline 4913 & $<3.0$ & $<3.0$ & $<3.0$ & - & - & - & - \\
\hline 4912 & $<3.0$ & $<3.0$ & $<3.0$ & - & - & - & - \\
\hline 4911 & $<3.0$ & $<3.0$ & $<3.0$ & - & - & - & - \\
\hline 4910 & 460 & 460 & $<3.0$ & - & - & - & - \\
\hline 4909 & $<3.0$ & $<3.0$ & $<3.0$ & - & - & - & - \\
\hline 4908 & $<3.0$ & $<3.0$ & $<3.0$ & - & - & - & - \\
\hline 4907 & 43 & 23 & $<3.0$ & - & - & - & - \\
\hline 4906 & $<3.0$ & $<3.0$ & $<3.0$ & - & - & - & - \\
\hline 4905 & $>1100$ & $>1100$ & $<3.0$ & - & - & - & - \\
\hline 4904 & $<3.0$ & $<3.0$ & $<3.0$ & - & - & - & - \\
\hline 4903 & $<3.0$ & $<3.0$ & $<3.0$ & - & - & - & - \\
\hline 4902 & 11 & 3.0 & $<3.0$ & - & - & - & - \\
\hline Kontrol positif & & & & + & + & - & - \\
\hline Kontrol negatif & & & & - & - & - & + \\
\hline
\end{tabular}

Pada tahap ini merupakan pendahuluan dari metode MPN yang dilakukan untuk memperkirakan ada atau tidaknya bakteri koliform pada sampel uji. Sampel uji melalui proses 3 seri pengenceran yang ditumbuhkan dalam media LTB. Sampel Uji dapat dinyatakan positif apabila pada tabung durham terbentuk gas hasil hidrolisis laktosa oleh enzim bakteri dari kelompok koliform. Laktosa pada senyawa sulfat digunakan oleh bakteri sebagai sumber karbon untuk melakukan fermentasi. Fosfat dan nutrisi yang tinggi dalam media ini akan mempercepat pertumbuhan bakteri E.coli dan meningkatkan pembentukan gas (Bridson 2006).

Tabel 3. Hasil uji MPN pada minuman yang dilakukan pada kantin rumah sakit X.

\begin{tabular}{lll}
\hline No Sampel & MPN Total Coliform & MPN E.coli \\
\hline 4894 (Air Minum) & 3,6 & 1,1 \\
4895 (Air Minum) & 9,2 & 5,1 \\
4896 (Air Minum) & $>23$ & 5,1 \\
4897 (Air Gula) & $>23$ & $<1,1$ \\
4898 (Es Batu) & $<1,1$ & $<1,1$ \\
4899 (Air Bersih) & 920 & - \\
4900 (Air Minum) & 16 & 3,6 \\
4901 (Air Minum) & $<1,8$ & - \\
\hline
\end{tabular}

Media LTB mengandung senyawa lauryl sulfat yang berfungsi untuk menghambat pertumbuhan mikroba non koliform karena sebagian bakteri non koliform tidak menghidrolisis laktosa. Keunggulannya ini membuat media LTB lebih direkomendasikan untuk pengujian koli (Wahjuningsih 2001).

UJI PENEGASAN (CONFIRMED TEST)

Uji penegasan pada penelitian ini menggunakan media EC Broth (Escherichia coli Broth) mendapatkan hasil 
yang di peroleh dari kantin rumah sakit $X$ adalah 11 sampel positif dan 7 sampel negatif sedangkan kantin rumah sakit $Y$ adalah 8 sampel positif dan 8 sampel negatif. Tabung yang telah diuji pada tes perkiraan menunjukkan hasil positif pada tabung durham kemudian dilakukan uji lebih lanjut ke dalam tes penegasan dengan media EC Broth diinkubasi selama 24 jam pada suhu $37^{\circ} \mathrm{C}$ (Feng et al. 2002) bila tabung media keruh diinterpretasikan sebagai positif E.coli (Juwita et al. 2014) (Gambar 2).
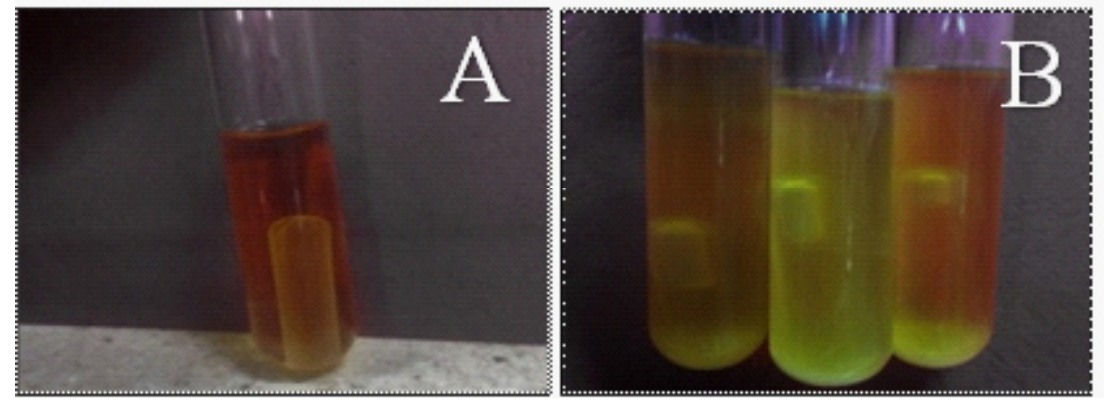

Gambar 1. Hasil negatif pada Media LTB (A), dan Hasil positif pada media LTB (B)

EC Broth berfungsi untuk diferensiasi fekal koliform dan uji konfirmasi untuk E.coli dari makanan dan sampel lingkungan. Bila media berubah dari kuning jernih menjadi kuning keruh dan terdapat gas di dalam tabung durham menunjukkan hasil positif terhadap bakteri koliform terutama E.coli (Lal \& Cheepthman 2007). Tabung menunjukkan hasil yang positif pada tabung durham karena terbentuknya gas yang terlihat pada Gambar 2.

Tabel 4. Hasil uji MPN pada minuman yang dilakukan pada kantin rumah sakit Y.

\begin{tabular}{lll}
\hline No Sampel & MPN Total Coliform & MPN E.coli \\
\hline 4918 (Air Gula) & $>23$ & 6,9 \\
4919 (Es Batu) & $<1,1$ & $<1,1$ \\
4920 (Air Minum Isi Ulang) & 20 & 6,9 \\
4921 (Air Bersih PAM) & 6,1 & - \\
\hline
\end{tabular}

\section{UJI PELENGKAP (COMPLETED TEST)}

Hasil positif yang ditunjukkan pada media EC Broth kemudian diuji ke dalam tes pelengkap. Tes pelengkap yang dilakukan dengan menggunakan media EMBA menunjukkan hasil positif pada kantin rumah sakit Y sedangkan kantin rumah sakit X menunjukkan hasil negatif (Gambar 3).

Pada $\mathrm{pH}$ yang cukup rendah fermentor laktosa seperti E.coli menghasilkan koloni ungu dengan kemilau hijau metalik, sedangkan kurang keasaman dapat menghasilkan warna coklat-merah muda koloni. Fermentor Non laktosa muncul seperti transparan atau pink. EMBA mengandung Enzimatik dari gelatin yang merupakan sumber nitrogen. Laktosa pada EMB membuat gram negative tumbuh terdiferensiasi berdasarkan sifatnya sehingga memproses laktosa. Eosin Y dan Methylene biru dari media EMBA merupakan pewarna yang bergabung untuk membentuk kompleks pada $\mathrm{pH}$ asam dan menghambat bakteri gram positif (eosin pada tingkat lebih rendah), sementara eosin berubah warna, ke ungu gelap, ketika media sekitar koloni menjadi asam (Himedia 2011).

Hasil pertumbuhan bakteri pada cawan petri menghasikan koloni ungu dengan kemilauan hijau metalik sehingga menunjukkan hasil positif pada media yang diduga koloni dari bakteri E.coli dengan batang Gram negatif 
dan koloni berwarna merah muda dan transparan diduga adalah bakteri Enterobacteria aerogenes yang memiliki sifat Gram negatif bentuk batang.
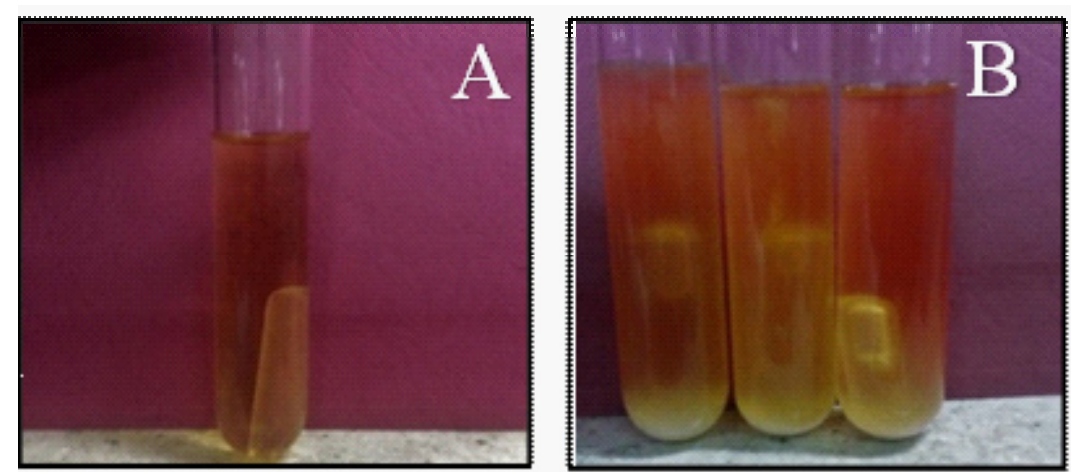

Gambar 2. Hasil negatif (A), dan positif (B) pada media EC Broth

\section{UJI PEWARNAAN GRAM}

Sampel dari kantin rumah sakit Y yang menunjukkan hasil positif dapat melakukan uji pewarnaan gram sebelum melewati proses uji biokimia. Uji pewarnaan gram pada sampel menghasilkan gram negatif (Gambar 4).

Bakteri gram negatif merupakan bakteri yang hanya memiliki sedikit lapisan peptidogligan dan tidak mengandung asam pada dinding selnya namun mengandung sejumlah polisakarida dan lebih rentan terhadap kerusakan mekanik dan kimia. Pewarnaan gram merupakan proses untuk mendeteksi dan mengidentifikasi bakteri. Perbedaan pada gram positif dan gram negatif terjadi karena penyusun peplidoglikan dan struktur selnya berbeda (Prasetyo 2009).

\section{UJI BIOKIMIA IMVIC}

\section{Uji Indol}

Hasil positif yang ditunjukkan pada media EMB kemudian diuji ke dalam uji biokimia. Uji biokimia terdiri dari uji indol, uji merah metil, uji Voges Praskauer, dan uji sitrat (Arifin 2013). Uji indol menunjukkan hasil negatif karena ditandai larutnya senyawa amino benzealdehid dalam air sehingga tidak membentuk warna merah seperti cincin sebagai pembentukan indol (Lumantouw et al. 2013) (Gambar 5).
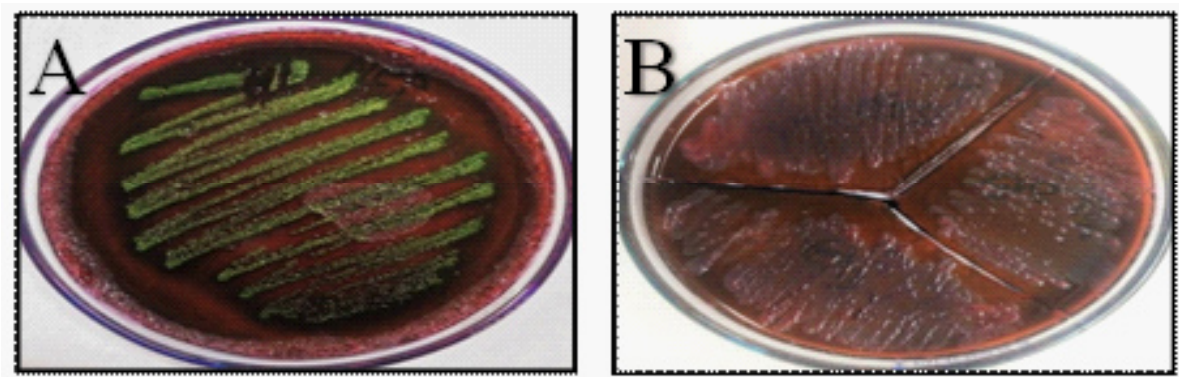

Gambar 3. Hasil biakan di media EMB diduga positif bakteri E. coli (A) dan hasil biakan di media EMB diduga negatif bakteri E. coli (B).

Cincin merah yang disebabkan oleh indol yang bereaksi dengan aldehida ketika diteteskan dengan reagen kovac. Bakteri E. coli akan teroksidasi oleh tryptophan sebagai sumber karbon (Sridhar 2006). Uji indol adalah salah satu komponen asam amino yang terdapat pada protein, sehingga asam amino umum digunakan oleh mikroorganisme 
untuk penguraian protein. E.coli menghasilkan enzim triptofanase sehingga penguraian gugus indol dapat dikatalis dari triptofan. Gugus indol pada media akan menumpuk sebagai produk buangan dan molekul triptofan (asam piruvat dan $\mathrm{NH} 4+$ ) kemudian digunakan untuk memenuhi kebutuhan zat hara mikroorganisme.

Tabel 5. Rekapitulasi hasil uji dari total sampel kedua rumah sakit

\begin{tabular}{lcccccccc}
\hline \multicolumn{2}{c}{ Sampel yang di uji } & $\begin{array}{c}\text { Uji } \\
\text { perkiraan }\end{array}$ & $\begin{array}{c}\text { Uji } \\
\text { penegasan }\end{array}$ & $\begin{array}{c}\text { Uji } \\
\text { pelengkap }\end{array}$ & Uji Indol & Uji MR & Uji VP & Uji Sitrat \\
\hline Rumah Sakit X & 18 & 14 & 11 & 0 & - & - & - & - \\
Rumah Sakit Y & 16 & 8 & 8 & 1 & - & + & - & + \\
Kontrol Positif & - & - & - & - & + & + & - & - \\
Kontrol Negatif & - & - & - & - & - & - & - & + \\
\hline
\end{tabular}

Uji Merah Metil (Methyl Red)

Uji Merah Metil (Methyl Red) digunakan untuk mendeteksi bakteri dengan asam campuran. Hasil pengamatan untuk Uji MR pada isolat bakteri E. coli adalah positif yang ditunjukkan dengan larutan berwarna merah (Gambar 6). Beberapa bakteri dapat memfermentasikan glukosa dan menjadikan berbagai produk bersifat asam sehingga dapat menurunkan $\mathrm{pH}$ media menjadi 5,0 atau lebih rendah. Penambahan indikator $\mathrm{pH}$ merah metil ke dalam kultur bakteri setelah inkubasi menunjukkan adanya perubahan $\mathrm{pH}$ menjadi asam. Merah metil berwarna merah pada lingkungan dengan $\mathrm{pH}$ 4,4 dan berwarna kuning dalam lingkungan dengan $\mathrm{pH}$ 6,2 (Widyawati 2012).

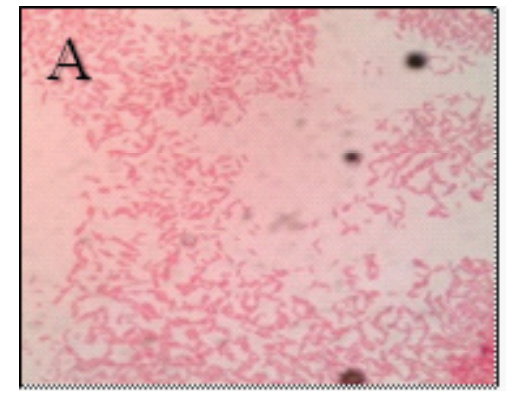

Gambar 4. Hasil pewarnaan gram dari sampel (A) dan kontrol positif(B)

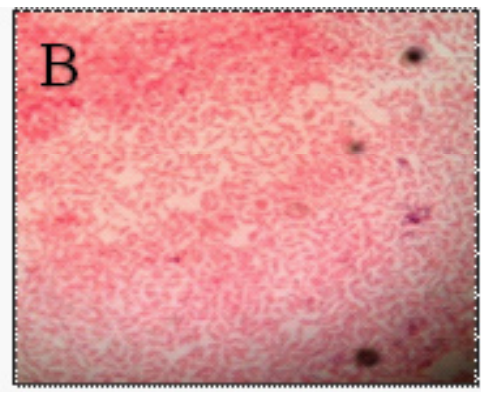

(B)

\section{Uji Voges-Proskauer}

Uji Voges-Proskauer yang dilakukan dalam pengamatan menunjukkan hasil negatif karena tidak adanya perubahan warna terhadap larutan VP (Gambar 7). Uji VP digunakan untuk mengidentifikasi bakteri melewati fermentasi karbohidrat oleh bakteri menjadi 2,3 butanadiol yang dijadikan sebagai produk utama sehingga terjadi penumpukan dalam media. Bila $\mathrm{KOH}$ ditambahkan pada media akan membentuk senyawa (asetoin) acetylmethylcarbinol namun proses tersebut tergantung pada pencernaan glukosa terjadi, bila glukosa pecah maka akan bereaksi dengan alpha-naftol. Perubahan warna memperjelas proses dari pembentukan asetoin menjadi warna merah cherry, sedangkan hasil yang tidak terjadi pembentukan asetoin menunjukan warna kuning coklat (Sridhar 2006). Asetoin merupakan perantara dalam produksi butilen glikol. Alpha-naftol berfungsi untuk katalis dan penguat warna (Kataria et al. 2013).

\section{Uji Sitrat}

Uji Sitrat umumnya digunakan untuk melihat kemampuan bakteri dengan menggunakan sitrat. . Uji sitrat pada pengamatan ini memberikan hasil positif (Gambar 8). Medium Koser sitrat berupa medium cair yang tidak mengandung indikator. Bila suatu bakteri mampu menggunakan sitrat sebagai sumber karbon dan energi dari bakteri, maka asam yang terkandung dalam media akan dihilangkan sehingga tidak terjadi perubahan warna atau sedikit biru 
(negatif), namun pada medium koser sitrat memiliki kemampuan menggunakan sitrat (positif) yang menunjukkan dengan kekeruhan yang menandakan tidak ada pertumbuhan (Mahardhika 2013).

Berdasarkan pengamatan yang telah dilakukan, hasil uji E.coli pada makanan siap saji di kantin rumah sakit dapat dilihat setelah sampel diinokulasikan pada media EMB, koloni yang tumbuh memiliki ciri- ciri seperti pada hygiene positif yang telah diberi kultur E.coli sehingga perlu diuji lanjutan dengan uji biokimia IMVIC. Hasil uji biokimia IMVIC pada sampel menunjukkan bahwa hasil uji indol negatif, uji merah metil positif, uji Voges-Proskauer negatif dan uji sitrat negatif. Ijong dan Dien (2011) mengatakan bahwa bakteri yang tumbuh pada media EMB namun
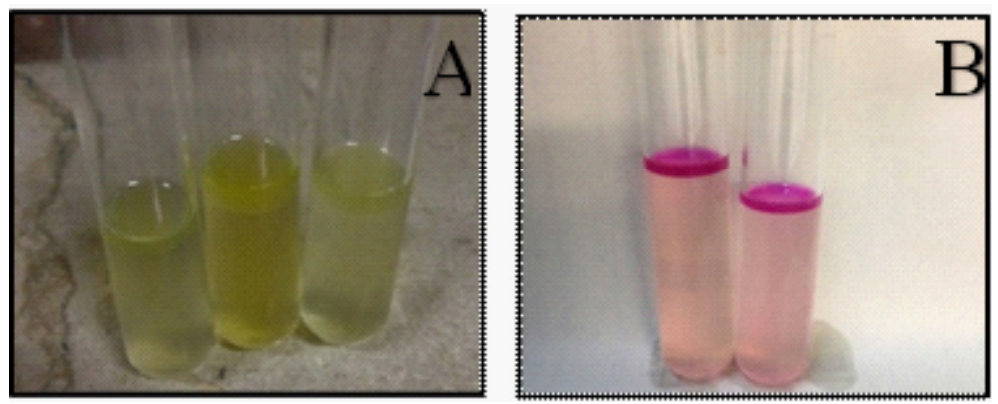

Gambar 5. Hasil uji indol pada sampel negatif(A), dan positif pada biakan E.coli (B)

tidak tumbuh pada uji biokimia dapat diduga bahwa hasil pengamatan yang diperoleh bukan E.coli.

Hasil dari penelitian ini menunjukkan bahwa sampel makanan yang diperoleh dari kantin rumah sakit X dan kantin rumah sakit $\mathrm{Y}$ dapat di katakan tidak mengandung bakteri E.coli namun kemungkinan adanya bakteri yang memiliki sifat yang sama dengan E.coli yaitu Citrobacter. Hal tersebut dikarenakan sampel menunjukkan warna hijau metalik (positif) pada media EMB namun menunjukkan hasil negatif pada uji biokimia IMVIC. Beberapa strain Citrobacter akan mengeluarkan warna kemilau hijau yang sama dengan E. coli bila di pantulkan oleh cahaya disebabkan metilen biru di media dari tingginya asam yang dihasilkan dari fermentasi (Lindquis 2004). Citrobacter
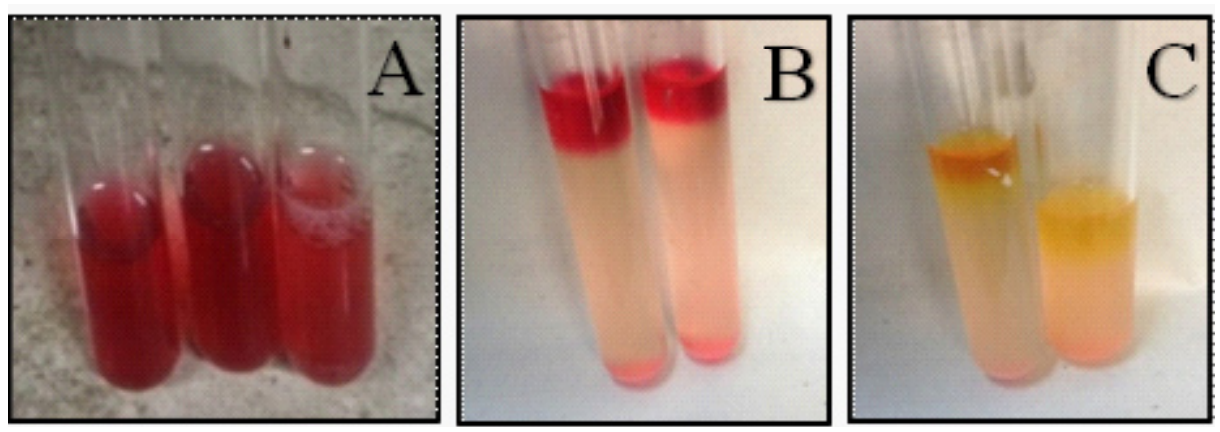

Gambar 6. Uji merah metil pada sampel menunjukkan hasil positif (A), pada kontrol negatif (B) dan kontrol positif $(\mathrm{C})$.

merupakan bakteri gram negatif, tidak berspora, tidak berkapsul, dan bergerak aktif dengan flagella. Bakteri ini mudah tumbuh pada media biasa dalam situasi aerob (Soemarno 2000).

\section{HUBUNGAN HYGIENE DAN SANITASI DENGAN KUALITAS MAKANAN DI KANTIN}

Pemilik kedai dapat di kategorikan telah memahami prinsip hygiene dan sanitasi bila makanan yang dikelola termasuk kedalam syarat yang telah di tentukan. Syarat tersebut dilakukan dengan menggunakan kuisioner yang 
mengacu pada permenkes 1096 Tahun 2011 tentang hygiene sanitasi jasaboga dan kepmenkes No. 942/Menkes/ SK/VII/2003. Kuisioner dibagikan di kantin rumah sakit X sebanyak 14 kedai dan kantin rumah sakit Y sebanyak 10 kedai. Berdasarkan hasil kuisioner, rumah sakit X sedikit lebih higienis dengan skor penilaian sebesar 96.24\%, dibandingkan rumah sakit $Y$ yang memiliki skor penilaian sebesar 94.8\% (Tabel 6).

Dari hasil analisis kuisioner yang telah didapat menyatakan bahwa pemilik kedai atau warung makanan umumnya telah memahami prinsip dari hygiene dan sanitasi. Hygiene dan sanitasi menjadi salah satu upaya kesehatan dengan cara memelihara dan melindungi kebersihan makanan sehingga mengurangi terjadinya kontaminasi pada makanan. Penyebab dominan terjadinya kontaminasi makanan adalah dari penjamah makanan itu sendiri (Ninie 2005). Kontaminan yang paling sering dijumpai pada makanan adalah bakteri koliform, Escherichia coli dan fekal

Tabel 6. Hasil kuisioner pemahaman hygiene bagi penjaja makanan di kedua RS

\begin{tabular}{|c|c|c|c|}
\hline \multirow{10}{*}{ 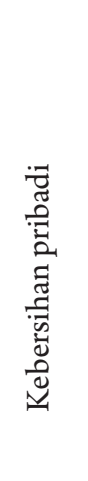 } & Objek Penelitian & $\begin{array}{l}\text { Kantin rumah } \\
\text { sakit X(\%) }\end{array}$ & $\begin{array}{l}\text { Kantin rumah } \\
\text { sakit } \mathrm{Y}(\%)\end{array}$ \\
\hline & Tidak menderita batuk-batuk atau pilek & $100 \%$ & $100 \%$ \\
\hline & Tidak menderita diare & $100 \%$ & $100 \%$ \\
\hline & Tidak berkuku panjang & $100 \%$ & $100 \%$ \\
\hline & Memakai penutup kepala & $71.4 \%$ & $90 \%$ \\
\hline & Memakai pakaian kerja & $71.4 \%$ & $70 \%$ \\
\hline & Menutup luka & $100 \%$ & $100 \%$ \\
\hline & Mencuci tangan & $92.8 \%$ & $80 \%$ \\
\hline & Tidak menggaruk kepala & $100 \%$ & $100 \%$ \\
\hline & SUB TOTAL & $91.95 \%$ & $92.5 \%$ \\
\hline \multirow{4}{*}{ 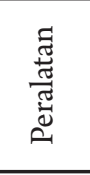 } & Di cuci setiap selesai di gunakan & $100 \%$ & $100 \%$ \\
\hline & Dikeringkan atau ditiriskan & $100 \%$ & $90 \%$ \\
\hline & Tidak memakai peralatan sekali pakai & $100 \%$ & $100 \%$ \\
\hline & SUB TOTAL & $100 \%$ & $96.7 \%$ \\
\hline \multirow{7}{*}{ 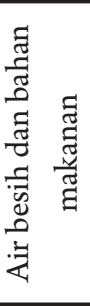 } & Berasal dari sumber yang memenuhi syarat & $100 \%$ & $100 \%$ \\
\hline & Tidak menggunakan air mentah untuk di minum & $100 \%$ & $100 \%$ \\
\hline & Bahan mentah dicuci terlebih dahulu & $100 \%$ & $100 \%$ \\
\hline & Bukan dari bahan kadaluarsa & $100 \%$ & $100 \%$ \\
\hline & Tidak mengandung bahan tambah pangan & $100 \%$ & $100 \%$ \\
\hline & Bahan tambah pangan sesuai takaran & $100 \%$ & $90 \%$ \\
\hline & SUB TOTAL & $100 \%$ & $98.3 \%$ \\
\hline \multirow{7}{*}{ 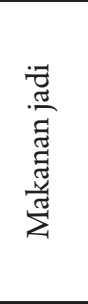 } & Dalam keadaan tertutup & $85.7 \%$ & $80 \%$ \\
\hline & Penutup makanan bersih & $85.7 \%$ & $80 \%$ \\
\hline & Makanan di ambil dalam keadaan tertutup & $78.5 \%$ & $80 \%$ \\
\hline & Tidak bersatu dengan bahan mentah & $92.8 \%$ & $100 \%$ \\
\hline & Jika lebih dari 6 jam dipanaskan kembali & $100 \%$ & $100 \%$ \\
\hline & Mengambil makanan menggunakan alat & $92.8 \%$ & $80 \%$ \\
\hline & SUB TOTAL & $89.25 \%$ & $86.7 \%$ \\
\hline \multirow{6}{*}{ 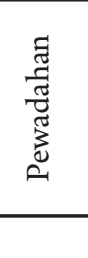 } & Melindungi dari debu dan serangga & $100 \%$ & $100 \%$ \\
\hline & Terdapat tempat cuci yang memadai & $100 \%$ & $100 \%$ \\
\hline & Air pencucian diganti & $100 \%$ & $100 \%$ \\
\hline & Sampah tidak menyebar & $100 \%$ & $100 \%$ \\
\hline & SUB TOTAL & $100 \%$ & $100 \%$ \\
\hline & RATA - RATA & $96.24 \%$ & $94.8 \%$ \\
\hline
\end{tabular}




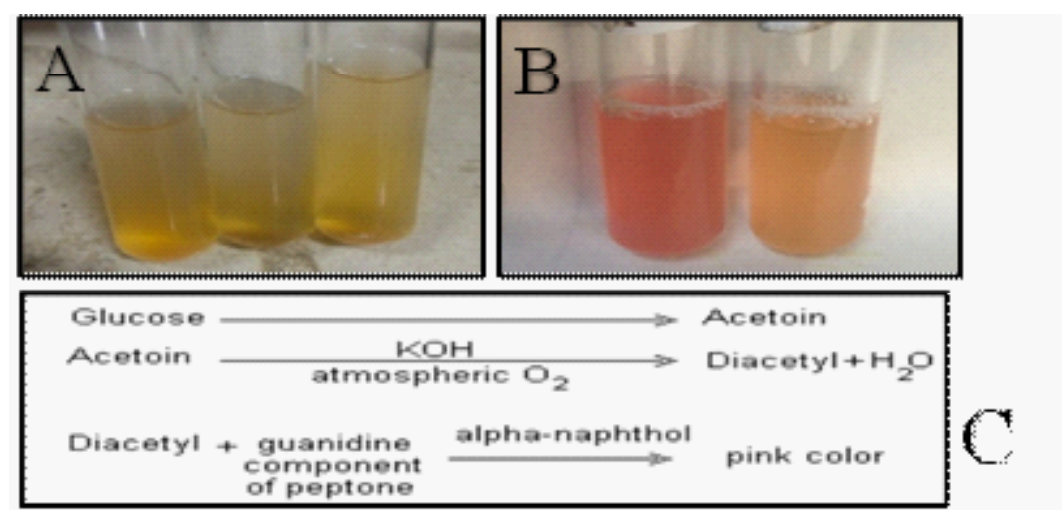

Gambar 7. Uji VP pada sampel menunjukkan hasil negatif (A), dan kontrol positif serta negatif

(B). Reaksi Voges-Proskauer pada uji biokimia IMVIC (Sridhar 2006) (C).

koliform. Bakteri ini berasal dari tinja manusia dan hewan, tertular ke dalam makanan karena perilaku penjamah yang tidak higienis, pencucian peralatan yang tidak bersih, kesehatan para pengolah dan penjamah makanan serta penggunaan air pencuci yang mengandung koliform, E. coli, dan fekal koliform (Depkes RI 1999).

\section{KONFIRMASI HASIL SAMPEL MAKANAN JAJANAN DI KANTIN RUMAH SAKIT X DAN KANTIN RUMAH} SAKIT Y

Sampel makanan menunjukkan positif pada saat ditumbuhkan di media EMB yang ditujukkan pada gambar 4 dengan melewati proses uji perkiraan dengan media LTB pada gambar 2 dan uji penegasan dengan media EC Broth pada gambar 3 terlebih dahulu, kemudian dilakukan pengujian biokimia untuk mengetahui positif E.coli atau tidak. Hasil uji biokimia pada sampel makanan menunjukan bahwa negative E.coli dengan hasil uji indol negatif, uji merah

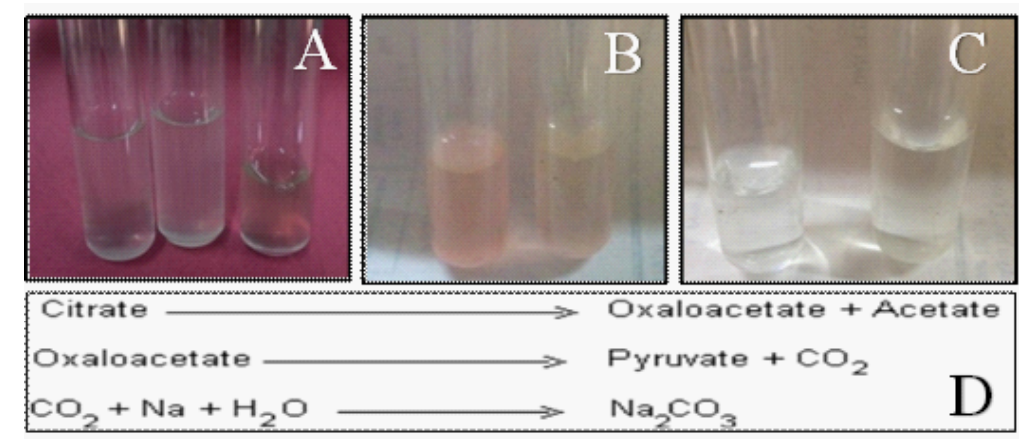

Gambar 8. Hasil uji sitrat pada sampel (A), kontrol negatif (B), dan kontrol positif (C).

Reaksi sitrat pada uji biokimia IMVIC (Sridhar 2006) (D)

metil positif, uji Voges-Proskauer negatif dan uji sitrat negative. Seharusnya positif E. coli memiliki uji yang dapat memfermentasi laktosa dan menghasilkan asam dan gas, indol dan metil red positif, tidak menggunakan sitrat (Ijong \& Dien 2011).

Uji makanan jajanan dari kedai atau warung makanan di kantin rumah sakit $\mathrm{X}$ dan rumah sakit $\mathrm{Y}$ telah diupayakan untuk mengambil yang diduga rentan akan bakteri, namun hasil yang pengamatan di dalam laboratorium menyatakan negatif. Hal ini dapat dikatakan bahwa kantin rumah sakit X dan kantin rumah sakit $Y$ memiliki prinsip hygiene dan sanitasi, karena hygiene dan sanitasi memiliki keterkaitan yang sangat erat misalnya bila hygiene sudah baik karena ingin mencuci tangan namun sanitasinya tidak tersedia cukup air bersih maka mencuci tangan tidak sempurna (Depkes RI 2004). 


\section{KESIMPULAN}

Sampel makanan yang diuji dari kedua lokasi rumah sakit menunjukkan negatif E.coli walaupun saat uji perkiraan dan penegasan menunjukkan adanya kemungkinan cemaran. Kemungkinan cemaran lain adalah keberadaan bakteri non-patogen Citrobacter yang dideteksi dari 1 sampel berdasarkan uji pelengkap dan biokimia. Makanan siap saji yang terdapat pada kantin rumah sakit $\mathrm{X}$ dan rumah sakit $\mathrm{Y}$ dinyatakan aman untuk dikonsumsi karena tidak mengandung bakteri E. coli. Berdasarkan hasil kuesioner yang diperoleh, sebagian besar pemilik kedai atau warung makan (diatas 94\%) telah memahami prinsip hygiene dan sanitasi yang baik dalam pengolahan makanan yang akan disajikan.

\section{UCAPAN TERIMAKASIH}

Penulis mengucapkan terima kasih kepada Balai Besar Teknik Kesehatan Lingkungan dan Pemberantasan Penyakit Jakarta (BBTKLPP) yang telah mengizinkan dan memfasilitasi penulis dalam melakukan penelitian. Bapak Arief Pambudi, M.Si selaku pembimbing I yang telah memberikan arahan kepada penulis selama proses penulisan skripsi berlangsung. Ibu Yulia Fitria Ningrum selaku pembimbing II yang telah memberikan bimbingan dan motivasi. Ibu Yetty selaku ketua laboratorium biologi BBTKLPP dan Ibu Yulia telah memberikan pengetahuan dan arahan kepada penulis selama proses penelitian.

\section{DAFTAR PUSTAKA}

Arifah IN. 2010. Analisis Mikrobiologi pada Makanan. [SKRIPSI]. Program Studi Teknologi Hasil Pertanian Fakultas Pertanian Universitas Sebelas Maret, Surakarta.

Bridson EY. 2006. The Oxoid Manual 9th Edition. Wade Road, Basingstoke, Hampshire RG24 8PW, England

Depkes RI. 1990. Peraturan Menteri Kesehatan Republik Indonesia No. 416/MenKes/Per/IX/1990. Jakarta: Departemen Kesehatan RI.

Depkes RI. 2003. Peraturan Menteri Kesehatan Republik Indonesia Nomor 942 Tahun 2003 Tentang Hygiene Sanitasi Makanan Jajanan. Jakarta: Kementerian Republik Indonesia.

Depkes RI. 2004. Keputusan Menteri Kesehatan Republik Indonesia Nomer 1204 Tentang Persyaratan Kesehatan Lingkungan Rumah Sakit. Jakarta: Departemen Kesehatan RI. Direktorat Jendral Pemberatasan Penyakit Menular dan Penyehatan Lingkungan.

Depkes RI. 2004. Hygiene Sanitasi Makanan dan Minuman. Dirjen PPM dan PL. Jakarta.

Depkes RI. 2010. Keputusan Menteri Kesehatan Republik Indonesia Nomer 492 Tentang Persyaratan Kualitas Air Minum. Jakarta: Kementerian Republik Indonesia.

Depkes RI. 2011. Buku Saku Petugas Kesehatan: Lintas Diare, Lima Langkah Tuntaskan Diare. Jakarta: Departemen Kesehatan Republik Indonesia.

Feng P, Weagant SD. 2002. Diarrheagenic Escherichia coli In Bacteriological analytical manual online. [Online.] U.S. Food and Drug Administration, Gaithersburg, Md. http://www.cfsan.fda.gov/ ebam./bam-toc.html. (Diakses tanggal 14 November 2016).

Himedia. 2011. Technical Data. http://himedialabs.com/TD/M078.pdf. (Diakses pada tanggal 16 November 2016). 
Ijong FG, Dien HA. 2011. Karakteristik bakteri pereduksi merkuri (Escherichia Coli) diisolasi dari perairan pantai teluk manado. Perikanan dan Kelautan Tropis. Vol 7(3): 103-108

Juwita U, Yuli H, Christine J. 2014. Jumlah bakteri coliform dan deteksi Escherichia coli pada daging ayam di Pekanbaru. JOM FMIPA. 1(2): 48-55

Kataria R, Hemraj, Singh G, Jalhan S, Jindal A. 2013. Pharmacological Activities on Glycyrrhiza Glabra-A Review. Asian J Pharmaceutical Clin Res. VI(1) p5-7.

Lal A, Cheeptham N. 2007. Eosin Methylen Blue Agar Protocol. ML Library American Society for Microbiology

Lumantouw SF, Febby EFK, Sendy BR, Marina FOS. 2013. Isolasi dan identifikasi bakteri yang toleran terhadap fungisida mankozeb pada lahan pertanian tomat di DesaTempok, KecamatanTompaso, Sulawesi Utara. Bios Logos. 3(2):73-77

Mahardika D. 2013. Pengujian Bakteri Escherichia coli Pada Air Sumur di Medan, Johor.[Tugas Akhir]. Analis Farmasi dan Makanan Fakultas Farmasi. Medan: Universitas Sumatera Utara

Marwanti. 2010. Keamanan Pangan dan Penyelenggaraan Makanan. Yogyakarta: Universitas Negeri Yogyakarta.

Ngafifi M. 2014. Kemajuan teknologi dan pola hidup dalam perspektif sosial budaya. Jurnal Pembangunan Pendidikan: Fondasi dan Aplikasi. 2(1): 33

Ninie, 2005. faktor Perilaku Penjamah Makanan Pada Laik Hygiene Kantin. Jurnal Penelitian. http://publichealthjournal.helpingpeopleideas.com/tag/penjamah-makanan-pada-kantin. (Diakses tanggal 20 November 2016).

Notoatmodjo. 2003. Meningkatkan Kualitas Pangan. Jakarta : Media Pustaka

Pemerintah Republik Indonesia. 2001. Peraturan Pemerintah Nomor 82 tahun 2001 Tentang Pengelolaan Kualitas Air dan Pengendalian Pencemaran Air. Jakarta

Prasetyo T. 2009. Pola resistensi kuman dari kultur darah di Lab mikro FKUI th 2001 - 2006 terhadap Kloramfenikol, Trimethoprim dan Tetrasiklin. [Skripsi]. FKUI: Jakarta

Sihite R. 2000. Tourism Industry. Surabaya : SIC.

Sridhar RPN. 2006. IMViC reaction.JJMMC. https://www.microrao.com/micronotes/imvic.pdf. (Di akses tanggal 20 November 2016).

Soemarno. 2000. Isolasi dan identifikasi bacteri klinik. Yogyakarta. Akademi Analis Kesehatan Yogyakarta Departemen Kesehatan RI.

Sunardi. 2014. Pemeriksaan Most Probable Number (MPN) Bakteri Coliform dan Coli Tinja Pada Jamu Gendong yabng Dijual di Pasar Besar Kota Palangkaraya. Fakultas Ilmu Kesehatan, Universitas Muhammadiyah Palangkaraya: Palangkaraya.

Tristyanto N. 2016. Buku Monograf : Uji Bakteriologi MPN Coliform dan Escherichia Coli Pada Air Baku Kolam Renang di Kota Malang. Jakarta: PT. Semesta Anugerah.

Wahjuningsih E. 2001. Substrat khromogenik - fluorogenik pada uji cemaran oli dalam air. Unitas. 9(2): 44-56. 